\title{
B-Lymphoblastic Lymphomas Evolving from Follicular Lymphomas Co-Express Surrogate Light Chains and Mutated Gamma Heavy Chains
}

Linda M. Slot, ${ }^{* \dagger}$ Robbert Hoogeboom, ${ }^{* \dagger}$ Laura A. Smit, ${ }^{*}$ Thera A.M. Wormhoudt, ${ }^{* \dagger}$ Bart J. Biemond, ${ }^{\ddagger}$ Monique E.C.M. Oud, ${ }^{*}$ Esther J.M. Schilder-Tol, ${ }^{*}$ André B. Mulder, ${ }^{\S}$ Aldo Jongejan, ${ }^{\Uparrow}$ Antoine H.C. van Kampen, ${ }^{\mathbb{\|} \|}$ Philip M. Kluin, ** Jeroen E.J. Guikema, ${ }^{\star \dagger}$ Richard J. Bende, ${ }^{* \dagger}$ and Carel J.M. van Noesel ${ }^{* \dagger}$

From the Departments of Pathology* and Haematology, ${ }^{\ddagger}$ and the Bioinformatics Laboratory, ${ }^{\complement}$ Klinische Epidemiologie, Biostatistiek en Bio-informatica (KEBB), Academic Medical Center Amsterdam, Amsterdam; the Lymphoma and Myeloma Center Amsterdam (LYMMCARE), ${ }^{\dagger}$ Amsterdam; the Departments of Laboratory Medicine ${ }^{\S}$ and Pathology,** University Medical Centre Groningen, University of Groningen, Groningen; and the Biosystems Data Analysis, Swammerdam Institute for Life Sciences, University of Amsterdam, Amsterdam, the Netherlands

Accepted for publication July 28, 2016

Address correspondence to Carel J.M. van Noesel, M.D. Ph.D., Department of Pathology, Academic Medical Center, Meibergdreef 9, 1105 AZ Amsterdam, the Netherlands. E-mail: c.j.vannoesel@ amc.uva.nl.

\begin{abstract}
Follicular lymphoma (FL) is an indolent B-cell non-Hodgkin lymphoma able to transform into germinal center-type diffuse large B-cell lymphoma. We describe four extraordinary cases of FL, which progressed to $\mathrm{TdT}^{+} \mathrm{CD} 2 \mathrm{O}^{-}$precursor B-lymphoblastic lymphoma (B-LBL). Fluorescence in situ hybridization analysis showed that all four B-LBLs had acquired a MYC translocation on transformation. Comparative genomic hybridization analysis of one case demonstrated that in addition to 26 numerical aberrations that were shared between the $\mathrm{FL}$ and $\mathrm{B}-\mathrm{LBL}$, deletion of $C D K N 2 A / B$ and $17 \mathrm{q} 11,14 \mathrm{q} 32$ amplification, and copyneutral loss of heterozygosity of $9 p$ were gained in the B-LBL cells. Whole-exome sequencing revealed mutations in FMN2, NEB, and SYNE1 and a nonsense mutation in KMT2D, all shared by the FL and B-LBL, and TNFRSF14, SMARCA2, CCND3 mutations uniquely present in the B-LBL. Remarkably, all four $F L-B-L B L$ pairs expressed IgG. In two B-LBLs, evidence was obtained for ongoing rearrangement of IG light chain variable genes and expression of the surrogate light chain. IGHV mutation analysis showed that all FL-B-LBL pairs harbored identical or near-identical somatic mutations. From the somatic gene alterations found in the $I G$ and non-IG genes, we conclude that the FLs and B-LBLs did not develop in parallel from early $\mathrm{t}(14 ; 18)$-positive $I G$-unmutated precursors, but that the B-LBLs developed from preexistent FL subclones that accumulated additional genetic damage. (Am J Pathol 2016, 186: 3273-3284; http://dx.doi.org/10.1016/j.ajpath.2016.07.027)
\end{abstract}

Follicular lymphomas (FLs) are the prototypic germinal center (GC)-derived B-cell non-Hodgkin's lymphomas ${ }^{1}$ and cytologically and histologically resemble normal GCs. In accordance, FLs share a gene expression profile with normal centroblasts and centrocytes ${ }^{2}$ and express somatically hypermutated B-cell antigen receptors, which in approximately $25 \%$ of cases are of the non-IgM isotype. $^{3,4}$

FLs have an indolent clinical behavior with a reported median survival of 8 to 10 years after diagnosis. ${ }^{1}$ However, $20 \%$ to $60 \%$ of FLs transform into higher-grade malignancies, an event associated with an aggressive clinical course, poor therapy responses, and short survival..$^{5}$ Usually, FLs transform into other GC-type lymphomas, most often diffuse large B-cell lymphomas (DLBCLs) or, less commonly, Burkitt-like lymphomas [referred to in the latest World Health Organization classification as B-cell lymphoma unclassifiable with features intermediate between DLBCL and Burkitt lymphoma (BL)]. ${ }^{5,6}$ Infrequently, these prototypic GC-like malignancies transform into precursor B-lymphoblastic

Supported by Dutch Cancer Society grants UVA 2009-4525 and (L.M.S. and T.A.M.W.) UVA 2006-3644 (R.H.).

L.M.S. and R.H. contributed equally to this work.

Disclosures: None declared. 
lymphomas (B-LBL). ${ }^{7-15}$ Studies on sporadic cases described so far revealed that such B-LBLs carried BCL2 translocations, indicative for a clonal relationship with the preceding FLs. Karyotype analyses showed a variety of chromosomal alterations gained in the B-LBLs, among which $M Y C$ locus translocations were most frequently observed [in 18 of $19(95 \%)$ of the described cases]. ${ }^{7-15}$ Lymphomas with two recurrent translocations, one of which being $M Y C$, are referred to as double-hit-B-cell lymphomas and have a dismal prognosis. ${ }^{6}$

Here, we analyzed four FLs that transformed into BLBLs. We demonstrate that these B-LBLs phenotypically and functionally display key features of early B cells and that, in addition to $M Y C$ translocations, also BCL6 gene translocation may accompany this infrequent mode of $\mathrm{FL}$ progression. Genome-wide copy number variation analysis and whole-exome sequencing (WES) of one of the transformed FLs demonstrated that a limited number of genomic alterations were gained in the B-LBLs, including deletions of the tumor suppressor genes $C D K N 2 A / B$ and $N F-1$ and mutations in TNFRSF14, SMARCA2, and CCND3.

\section{Materials and Methods}

\section{Patient Material}

The clinicopathologic characteristics of the four patients with a FL that transformed into a B-LBL are shown in Table 1. This study was conducted in accordance with the ethical standards in our institutional medical committee on human experimentation, as well as in agreement with the Helsinki Declaration of 1975, revised in 1983.

Table 1 Four Patients with a FL that Has Transformed into a B-LBL

\begin{tabular}{llllll}
\hline & & \multicolumn{2}{c}{ Age, } & \multicolumn{2}{l}{ Years from } \\
Patient & Sex & years & Diagnosis & FL diagnosis & Location \\
\hline TF1a & F & 57 & FL & 0 & Lymph node \\
TF1b & & & B-LBL & 2 & Epicardium \\
TF2a & F & 51 & FL & 0 & Lymph node \\
TF2b & & & B-LBL & 1 & Mouth \\
TF2c & & & B-LBL & 2 & Mouth \\
TF3a & F & 24 & FL & 0 & Lymph node \\
TF3b & & & FL & 2 & Lymph node \\
& & & B-LBL & 2 & Lymph node \\
TF4a & M & 54 & FL & 0 & Lymph node \\
TF4b & & & DLBCL & 1 & Abdominal wall \\
TF4c & & & B-LBL & 1 & Retroperitoneum \\
\hline
\end{tabular}

In TF1b, TF2 $b$, and TF4 $b$ the preexisting $F L$ was no longer present, whereas in TF3b both the FL and B-LBL were detected. The biopsies of TF2b and TF2C were both taken from the mucosa of the jaw.

Patients TF1, TF2, TF3, and TF4 all died within 2 years after FL diagnosis.

F, female; M, male; B-LBL, precursor B-lymphoblastic lymphoma; FL, follicular lymphoma.

\section{Clinicopathologic History of the Four Patients}

\section{TF 1}

A FL grade I was diagnosed, which was treated with chlorambucil. After 1 year a B-LBL was diagnosed, and the patient was treated with high-dose chemotherapy consisting of iphosphamide, etoposide, methotrexate, and two consolidation cycles with cytarabine, etoposide, and methotrexate. Complete remission was reached. A few weeks later progression of the disease occurred, and no further treatment was undertaken. The patient died subsequently.

\section{TF 2}

A FL grade I was diagnosed, which was not treated. Two years later a B-LBL was diagnosed, which was treated with daunorubicin, vincristine, prednisone, asparaginase, and methotrexate. Three months later the B-LBL reoccurred. The patient was treated with dexamethasone, but died a few weeks later.

\section{TF 3}

A FL grade I was diagnosed. Two years later, laboratory evaluation showed a leukocyte count of $10.7 \times 10^{9} / \mathrm{L}$ with $38 \%$ atypical lymphocytes. Immunophenotyping demonstrated two lymphocytic populations, that is, one population of mature monoclonal $\mathrm{B}$ cells and a distinct population of lymphoid blasts. Combined chemotherapy with cytarabine, etoposide, and methotrexate was started. Complete remission was established after two additional courses of vincristine, dexamethasone, and adriamycin. Consolidation therapy consisted of cytarabine and asparaginase. Shortly thereafter the disease relapsed. Local radiotherapy was given. The patient died a few weeks later.

\section{TF 4}

A FL was diagnosed, which was treated with eight cycles of rituximab, cyclophosphamide, doxorubicin, vincristine, and prednisolone. A year later, positron emission tomography-computed tomography scan showed lesions in the abdominal wall and in the retroperitoneum, which pathologically turned out to be a DLBCL and a B-LBL, respectively. Rituximab combined with dexamethasone, high-dose cytarabine and cisplatin treatment was started, but eventually the patient died several months later.

\section{Immunohistochemistry}

Immunohistochemical stainings were performed on acetonefixed cryostat sections and formalin-fixed paraffinembedded tissue using Powervision ${ }^{+}$detection system (Immunovision Technologies, Daly City, CA). Monoclonal antibodies used were CD20 (B-Ly1), CD21-L (DRC-1), BCL2 (124), BCL6 (PG-B6P), CD79a (HM57), CD19 (HD37), Ig $\lambda$ (A193), Igא (A191) (Dako, Glostrup, Denmark); CD10 (CALLA) and PAX5 (24) [Becton and 
Dickinson (BD), Erembodegem-Aalst, Belgium]; and CD3 (SP7; Labvision, Neomarkers, Fremont, CA). Terminal deoxynucleotidyl transferase (TdT) was stained with a polyclonal serum (Klinipath, Duiven, the Netherlands).

\section{RNA Isolation, cDNA Synthesis}

RNA was isolated using TRIzol reagent (Invitrogen, Breda, the Netherlands) and cDNA was synthesized. ${ }^{3}$ Immunoglobulin heavy chain variable region (IGHV) transcripts were amplified by PCR. ${ }^{16,17}$ In some experiments, IGHV-PCR products were cloned in pTOPO-TA-vectors and sequenced. IGHV genes were identified using V-Quest version 3.3 (http://www. imgt.org/ $I M G T \_v q u e s t / v q u e s t$ ? livret $=0 \&$ Option $=$ human Ig). ${ }^{18}$ VpreB and Lambda5 were amplified with the respective primer pairs: 5'-CTCATGCACTTTGTCTACTG-3' $/ 5^{\prime}$-CTGGCTCTTGTCTGATTGTGAG- $3^{\prime}$ and $5^{\prime}$-CTCCTGTCCTGCTCATGCTG- $3^{\prime} / 5^{\prime}$-GTACACACCGATGTCATGGTCG- $3^{\prime}$. The BCL2 PCR was performed on DNA, as described. ${ }^{19}$

\section{FISH}

Chromosomal aberrations were investigated in $4-\mu \mathrm{m}$ thick formalin-fixed paraffin-embedded tissue sections by fluorescence in situ hybridization (FISH). A segregationdetection assay was used to detect breaks in $B C L 2$ (probe Y5407), BCL6 (probe Y5408), and MYC (probe Y5410) (Dako).

\section{Cell Sorting}

Lymph node suspensions of TF3b were stained with CD19-allophycocyanin, CD10-peridinin-chlorophyll protein complex-cyanine 5.5, and CD20-fluorescein isothiocyanate monoclonal antibodies (BD). Cells were sorted in small $\mathrm{CD} 19^{+} \mathrm{CD} 10^{+} \mathrm{CD} 20^{\text {lo }}$ cells, small $\mathrm{CD} 19^{+} \mathrm{CD} 10^{+} \mathrm{CD} 20^{\text {hi }}$ cells, small $\mathrm{CD} 19^{+} \mathrm{CD} 10^{-} \mathrm{CD} 20^{\mathrm{hi}}$ cells, and large $\mathrm{CD} 19^{+} \mathrm{CD} 10^{+} \mathrm{CD} 20^{\text {lo }}$ cells by using a FACSAria (BD).

\section{Comparative Genomic Hybridization Array}

Genomic DNA was isolated using DNeasy kit (Qiagen, Hilden, Germany) and analyzed for copy number variation using HumanCytoSNP-12 BeadChips (Illumina, San Diego, CA). Processing of DNA samples, hybridization, staining, and scanning of the BeadChips were performed according to the Illumina Infinium II protocol at the array facility of ServiceXS (Leiden, the Netherlands). Data were analyzed using Illumina GenomeStudio software version 2009.2. The $\log R$ ratio and the $B$ allele frequency data were processed into the OverUnder plugin as described previously, ${ }^{20}$ and copy numbers were calculated. Because of lack of normal tissue, it cannot be excluded that some of the copy number variation are germline polymorphisms.

\section{WES}

Genomic DNA was amplified using the illustra GenomiPhi V2 DNA amplification kit (GE Health Care, Little Chalfont, United Kingdom). Unamplified DNA of the B-LBL isolated from blood was used to control for amplification errors. Fragmentation was performed with the Covaris sonicator (GC Biotec, Alphen aan de Rijn, the Netherlands). Library preparation was performed using Solid chemistry. An exome capture was performed with whole-exome capture EZ version 3 of Nimblegen (Roche, Almere, the Netherlands) with platform-specific adaptors and blockers. Clonal amplification of the captured library was performed by emulsion PCR (Life Technologies, Carlsbad, CA). Finally, samples were sequenced on a Solid $5500 \mathrm{xl}$ sequencer. Obtained data were processed according to the NGS pipeline described by Houten et al. ${ }^{21}$ Because of the lack of normal tissue, only differential variants between FL and B-LBL could be determined. In addition, in our WES data we also checked for mutations in sets of 92 and 40 genes, previously found to be mutated in WES data of FLs and B-cell acute lymphoblastic leukemias (B-ALLs), respectively (Supplemental Table S1). ${ }^{5,2-26}$ Eleven mutations, in 10 genes identified in TF3b, were validated by Sanger sequencing in TF3b, and, in addition, these 11 mutations were examined in TF1a, TF2a, and TF2c. Moreover, enhancer of zeste homolog 2 (EZH2), which is frequently mutated in FL, was screened for mutations in TF1a and TF3b.

\section{Results}

Histology and Phenotype of Four FLs before and after Transformation into B-LBLs

Before transformation, the four FLs (TF1a to TF4a) displayed a follicular growth pattern with a characteristic phenotype, that is, $\mathrm{CD} 20^{+}, \mathrm{CD}_{79 \mathrm{a}^{+}}, \mathrm{BCL}^{+}$cells co-expressing the $\mathrm{GC}$ markers CD10 and BCL6 that expanded in networks of follicular dendritic cells (Tables 1 and 2). After B-LBL transformation, the follicular architecture of TF1, TF2, and TF4 was lost. The tumor cells of all four cases still expressed CD79a, CD10, and BCL2 but were devoid of CD20. In addition, all BLBLs expressed TdT. In the TF2b B-LBL approximately $10 \%$ of the tumor cells stained positive for TdT. However, no TdT expression was observed in the TF2c biopsy. In TF3b, the follicular growth pattern was in part retained and alternated with sheets of lymphoblastic cells (Figure 1). To analyze the molecular features of the entities in TF3b, CD19 ${ }^{+}$cells of lymph node suspensions underwent fluorescence-activated cell sorting based on size and expression of CD20 and $\mathrm{CD} 10$, in: i) small $\mathrm{CD} 19^{+} \mathrm{CD} 10^{+} \mathrm{CD} 20^{\text {lo }}$ cells, ii) small $\mathrm{CD} 19^{+} \mathrm{CD} 10^{+} \mathrm{CD} 20^{\mathrm{hi}}$ cells, iii) small $\mathrm{CD} 19^{+} \mathrm{CD} 10^{-} \mathrm{CD} 20^{\mathrm{hi}}$ cells, and iv) large $\mathrm{CD} 19^{+} \mathrm{CD} 10^{+} \mathrm{CD} 20^{\mathrm{lo}}$ cells. Both $\mathrm{CD} 20^{\mathrm{lo}}$ fractions expressed TdT, as determined by RT-PCR, demonstrating that these fractions represent the B-LBL 
Table 2 Immunophenotypes of Four Lymphomas before and after Progression

\begin{tabular}{|c|c|c|c|c|c|c|c|c|c|c|c|c|}
\hline Patient & Diagnosis & CD20 & $\mathrm{FDC}$ & CD10 & BCL6 & BCL2 & $\mathrm{TdT}$ & Pax5 & CD79a & CD19 & $\operatorname{Ig} \lambda$ & Ig $\kappa$ \\
\hline TF1a & $\mathrm{FL}$ & + & + & + & + & + & - & + & + & + & + & - \\
\hline TF1b & B-LBL & - & ND & + & - & + & + & + & + & + & + & - \\
\hline TF2a & $\mathrm{FL}$ & + & + & + & + & + & - & + & + & ND & ND & ND \\
\hline TF2b & B-LBL & - & ND & + & + & + & + & + & + & + & + & - \\
\hline TF2c & B-LBL & - & ND & + & + & + & - & + & + & + & + & - \\
\hline TF3a & $\mathrm{FL}$ & + & + & + & + & + & - & + & + & ND & ND & ND \\
\hline \multirow[t]{2}{*}{ TF3b } & $\mathrm{FL}$ & + & + & + & + & + & - & + & + & + & ND & ND \\
\hline & B-LBL & - & - & + & - & + & + & + & + & + & ND & ND \\
\hline TF4a & $\mathrm{FL}$ & + & ND & + & + & + & - & + & + & + & ND & ND \\
\hline TF4b & DLBCL & - & - & + & - & + & - & + & + & ND & ND & ND \\
\hline TF4C & B-LBL & - & - & + & - & + & + & + & + & ND & ND & ND \\
\hline
\end{tabular}

Protein expression of CD20, CD21-L, CD10, BCL6, BCL2, TdT, Pax5, CD79a, CD19, and Ig $\lambda$, as determined by IHC on formalin-fixed paraffin-embedded and frozen sections.

$\mathrm{BCL}$, B-cell lymphoma; B-LBL, precursor B-cell lymphoblastic lymphoma; FDC, follicular dendritic cells (as determined by CD21-L staining); FL, follicular lymphoma; LN, lymph node; ND, not determined due to lack of appropriate patient material; TdT, terminal deoxynucleotidyl transferase.

(Supplemental Figure S1). Of note, the FL of TF4 transformed into a DLBCL before transforming into B-LBL (Table 1).

\section{The Four FLs and Successive B-LBLs Express Clonally Related Somatically Mutated Ig $\gamma$ Heavy Chains}

IGHV gene analysis showed that in all patients the FL and B-LBL were of the same clonal origin, harboring identical IGHV rearrangements (Table 3 ). In TF3b, all four fractions undergoing fluorescence-activated cell sorting, including the small $\mathrm{CD} 19^{+} \mathrm{CD} 10^{-} \mathrm{CD} 20^{\text {hi }}$ cells, harbored an identical IGHV rearrangement, suggesting that this population is either a $\mathrm{CD} 10^{-}$subclone of the FL or represents a stage intermediate between the FL and B-LBL. In accordance with their GC phenotype, all four FLs harbored somatically mutated IGHV. Intriguingly, all four lymphomas expressed IgG, as determined by RT-PCR, instead of the commonly found $\mathrm{IgM}$ in $\mathrm{FL}^{4}$ (Table 3). Because of the poor DNA quality, the IGHV of the TF3a FL could only be investigated from framework 2 . We were unable to determine the IGHV of the TF4b DLBCL due to lack of material.

All four FL/B-LBL pairs harbored high numbers of shared somatic IGHV mutations (Figure 2), further underscoring their clonal relationship. Comparison of individual molecular IGHV clones of TF1 and TF3 showed intraclonal IGHV sequence variation of the FLs but not of the B-LBLs. Particularly the CD20 hi FL cell fractions of TF3b showed high intraclonal IGHV sequence variation, whereas intraclonal IGHV sequence variation was not detected in the CD20 $0^{\mathrm{lo}} \mathrm{B}-\mathrm{LBL}$ cell fractions (Figure 2).
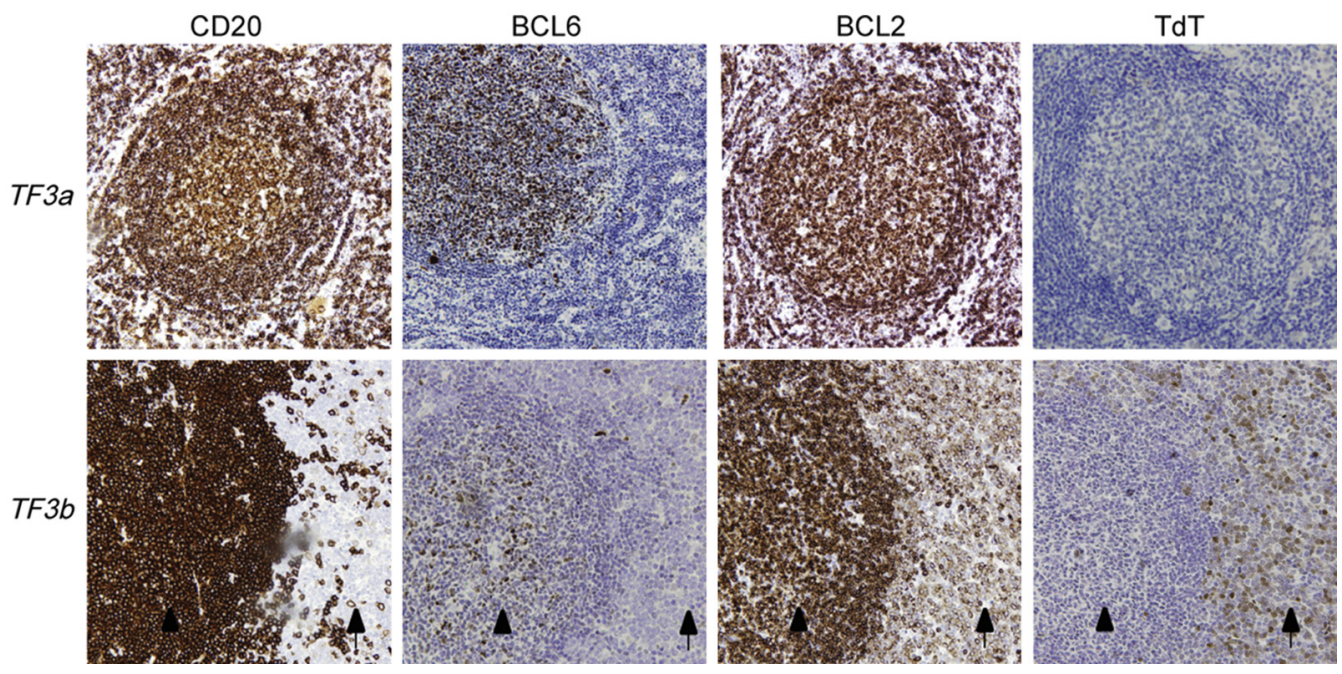

Figure 1 Histology and immunophenotype of TF3 before and after transformation. TF3a showed a follicular growth pattern and expressed CD20, BCL6, and BCL2. After transformation part of the tumor cells of TF3b retained a follicular growth pattern (as indicated by an arrowhead), which was alternated by sheets of lymphoblastic cells (as indicated by an arrow). The FL cells still expressed CD20, BCL6, and BCL2, whereas the B-LBL cells lacked expression of CD20 and BCL6 but expressed TdT. Original magnification, $\times 100$. BCL, B-cell lymphoma; B-LBL, B-lymphoblastic lymphoma; FL, follicular lymphoma; TdT, terminal deoxynucleotidyl transferase. 
Table 3 IGHV and IGLV Rearrangements of the Four FLs and in Their Ensuing B-LBL

\begin{tabular}{llllll}
\hline Patient & Diagnosis & Subclass & IGHV rearrangement & Mut no. (shared with FL) & IGLV rearrangement \\
\hline TF1a & FL & IgG & IGHV4-61/NA/IGHJ5a & 22 & IGLV2-18/IGLJ2/3a \\
TF1b & B-LBL & IgG & IGHV4-61/NA/IGHJ5a & 27 (19) & IGLV3-21/IGLJ3b \\
TF2a & FL & IgG & IGHV3-20/NA/IGHJ6b & 23 & IGLV1-36/IGLJ3b \\
TF2b & B-LBL & IgG & IGHV3-20/NA/IGHJ6b & $23(23)$ & Polyclonal \\
TF3a & FL & ND & IGHV1-69/IGHD1-26/IGHJ6c & $10^{*}$ & ND \\
TF3b ${ }^{\dagger}$ & FL (CD10 $\left.{ }^{\text {hi }}\right)$ & IgG & IGHV1-69/IGHD1-26/IGHJ6c & 17 & IGLV4-69/IGLJ2/3a \\
& FL (CD10 low $)$ & IgG & IGHV1-69/IGHD1-26/IGHJ6c & 15 & IGLV4-69/IGLJ2/3a \\
& B-LBL (S) & IgG & IGHV1-69/IGHD1-26/IGHJ6c & $15(14)$ & IGLV4-69/IGLJ2/3a \\
& B-LBL (L) & IgG & IGHV1-69/IGHD1-26/IGHJ6c & $15(14)$ & IGLV4-69/IGLJ2/3a \\
TF4a & FL & IgG & IGHV3-73/IGHD1-7/IGHJ5*02 & 21 & ND \\
TF4b & DLBCL & ND & ND & ND & ND \\
TF4c & B-LBL & IgG & IGHV3-73/NA/IGHJ5*02 & $25(18)$ & ND \\
\hline
\end{tabular}

*IGHV SHM was determined starting from FR1 in all instances, except for TF3a, in which SHMs were determined starting from FR2, and TF4, in which SHM could not be determined in the first part of FR1.

${ }^{\dagger}$ Lymph node suspensions of TF3b were sorted in four fractions (Supplemental Figure S1 and text).

B-LBL, precursor B-cell lymphoblastic lymphoma; DLBCL, diffuse large B-cell lymphoma; FL, follicular lymphoma; FR, framework; L, large; Mut, mutation; NA, not applicable; ND, not determined; S, small; SHM, somatic hypermutation.

\section{Some B-LBLs Show Ongoing Light Chain Rearrangement and Express Surrogate Light Chains}

The FL TF1a was found to express an IGLV2-18/IGLJ2/3a rearrangement (Table 3). Interestingly, after transformation a different monoclonal Ig $\lambda$ variable region (IGLV) rearrangement was amplified out of the TF1b B-LBL, that is, IGLV3-21/IGLJ3b. Amplification of IGLV of DNA followed by GeneScan analysis revealed that in both the FL and the B-LBL of TF1 two IGLV rearrangements were present (data not shown). One of these IGLV rearrangements was of the same length before and after transformation. In accordance with the IGLV sequence analysis, the second IGLV rearrangement in the B-LBL of TF1b was of a different length than that of the FL of TF1a. The IGLV3-21 gene segment, identified in the B-LBL, is located more upstream in the IGLV locus than the IGLV2-18 gene segment of the FL. Most likely, the IGLV3-21 rearrangement of the TF1b B-LBL has emerged by secondary rearrangement of the IGLV. Similarly, the IGLVI-36/IGLJ3b rearrangement detected in FL TF2a was not found in B-LBL TF2b. In TF2b an oligoclonal rearrangement pattern was seen by GeneScan analysis (data not shown). In all cell populations of TF3b undergoing fluorescence-activated cell sorting, an identical IGLV4-69/IGLJ2/3a rearrangement was observed. In accordance, a monoclonal IGLV region of identical length was observed by GeneScan analyses (data not shown).

The expression of the Ig light chain was also assessed by immunohistochemistry (IHC) on cryostat sections. The tumor cells of both the FL and B-LBL of TF1 expressed $\operatorname{Ig} \lambda$, but no Igא (Table 2), confirming the RT-PCR analyses. In the B-LBL TF2b, Ig $\lambda$ was exclusively detected. IGLV expression of FL TF2a and all TF3 and TF4 samples could not be investigated by IHC due to lack of frozen tissue.
It has been described that B-LBLs express the surrogate light chain $(\psi \mathrm{L})$, which is composed of two proteins, VpreB and $\lambda 5 .{ }^{27}$ RT-PCR analyses revealed that both the B-LBL of TF1b and TF2b indeed expressed VpreB and $\lambda 5$, whereas the preceding FL of TF1a and TF2a did not (Figure 3). In TF3a and TF3b, VpreB and $\lambda 5$ expression were not detected. Because of the lack of material, VpreB and $\lambda 5$ expression was not assessed in TF4.

\section{All Four B-LBLs Acquired a MYC Gene Translocation}

In accordance with the immunohistochemical data, the FLs of TF1a, TF3a, and TF4a harbored translocations of the $B C L 2$ gene as detected by segregation FISH, and these translocations were also detected after histologic transformation. Unfortunately, the $B C L 2$ FISH on TF2a was not interpretable; however, in the TF2c B-LBL a $B C L 2$ translocation was detected (Table 4). In all four patients, $M Y C$ gene translocations were identified after histologic transformation. In addition, a 3q27 break, involving $B C L 6$, was found in the FL of TF1a, whereas after progression no split signals were detected. In contrast, the B-LBL of TF2c showed a 3q27 break only after transformation. In TF3 and TF4, a 3q27 breakage was not detected in any of the biopsies. Both in TF3 and TF4, BCL6 protein expression decreased on transformation, as detected by IHC (Figure 1).

\section{Genome-Wide Analyses of TF3 before and after Transformation}

To further uncover the genomic aberrations that accompanied progression of the FL of TF3, the sorted cell populations were analyzed by comparative genomic hybridization (CGH). The number of genomic aberrations in the FL of TF3b was similar to two control FLs. In total, the FL and B-LBL fractions of TF3b shared 26 genomic 


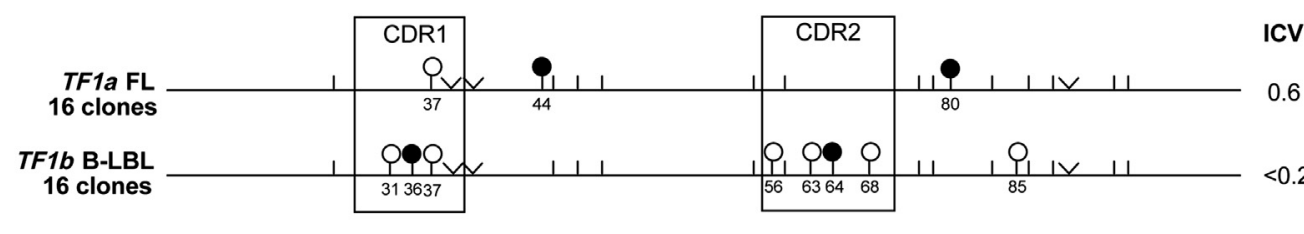

ICV
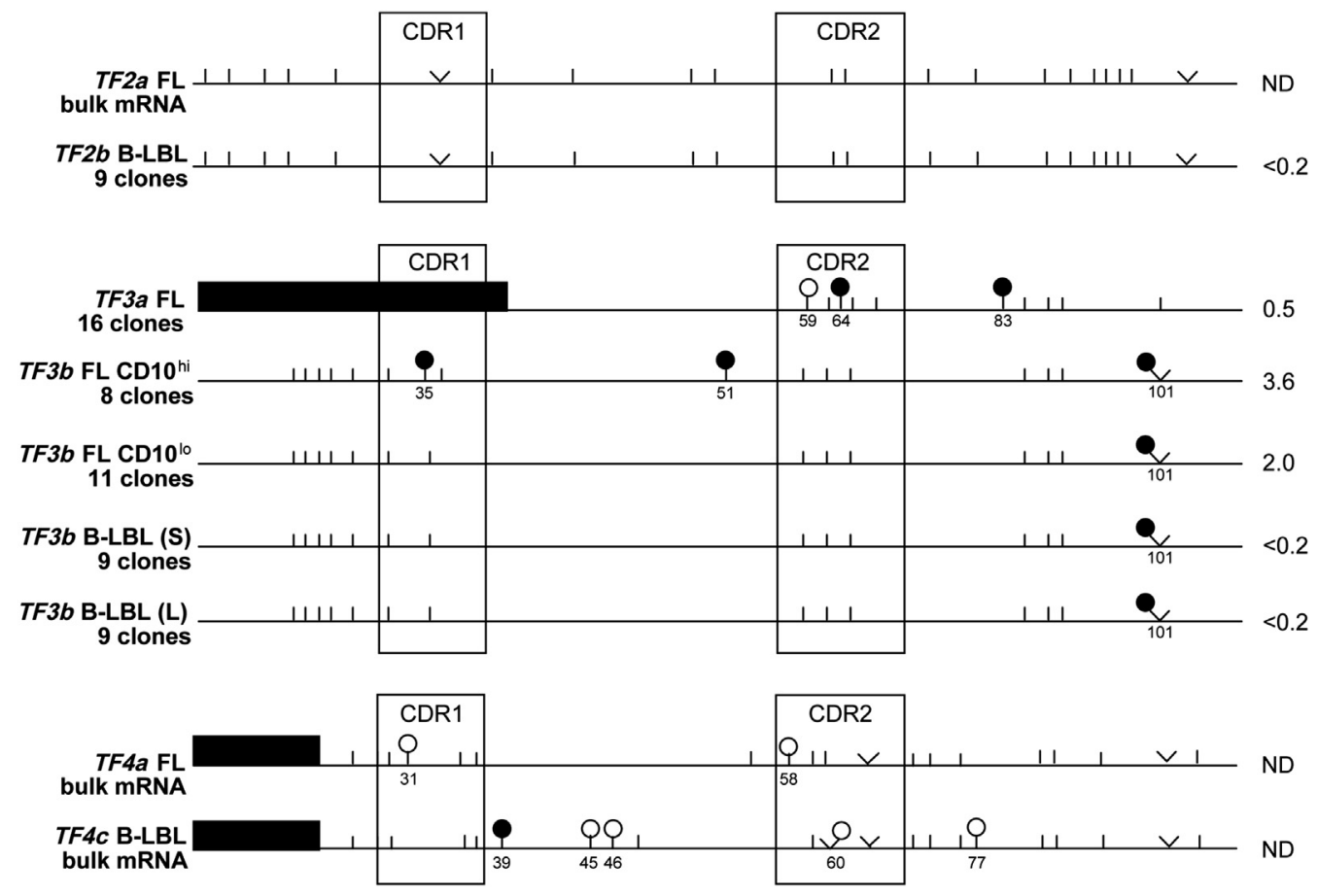

Figure 2 IGHV configurations of FL and B-LBL. Schematic representation of IGHV consensus sequences of TF1 to TF4 before and after progression. Vertical bars correspond to shared mutations between the FL and B-LBL. V corresponds to two shared mutations in the same codon. Nonshared replacement and silent mutations are indicated by closed and open lollipop symbols, respectively. Codon numbering is according to V-Quest version 3.3 (http://www.imgt.org/IMGT_ vquest vquest? livret $=0 \& 0$ ption $=$ humanIg) ${ }^{18}$ Black boxes indicate parts of the IGHV gene that were not sequenced. B-LBL, B-lymphoblastic lymphoma; CDR, complementarity-determining region; FL, follicular lymphoma; ICV, degree of intraclonal variation; L, large; ND, not determined; S, small.

aberrations (Figure 4A), underscoring their clonal relationship. The shared aberrations comprised three amplifications, three deletions, and copy-neutral loss of heterozygosity $(\mathrm{CN}-\mathrm{LOH})$ in 20 regions, including deletion of 22q11 and $\mathrm{CN}-\mathrm{LOH}$ of $6 \mathrm{q} 21$ and $7 \mathrm{q} 33$, which are all commonly observed in $\mathrm{FLs}^{28}$ (Table 5). Interestingly, these 26 shared aberrations also contained regions previously described to be associated with transformation of FL into high-grade lymphomas other than B-LBL, such as deletion of $1 \mathrm{p} 36 .{ }^{28}$ It was noted by $\mathrm{CGH}$ that $M Y C$ was amplified in the FL before translocation (Figure 4A). The B-LBL harbored only a limited set of aberrations in addition to the aberrations already present in the FL, that is, CN-LOH of 9p, amplification of $14 \mathrm{q} 32$, and deletion of $17 \mathrm{q} 12$. The affected region of 9p included CN-LOH of JAK2 and PAX5. Importantly, a small region of $9 \mathrm{p} 21$ was deleted, which contains the tumor suppressor genes $C D K N 2 A / B$ (encoding p15 and p16) and $M T A P$ (Figure $4 \mathrm{~B}$ ). Genes amplified at $14 \mathrm{q} 32$ include the proto-oncogenes TCL1, BCL11, and AKT1 (PKB). The tumor suppressor gene $N F-1$ is among the genes deleted on chromosome 17. In Supplemental Table S2, the affected genes in $9 \mathrm{p}, 14 \mathrm{q} 32$, and $17 \mathrm{q} 12$ are listed. In the CD10 fraction, an amplification of chromosome 12 was gained compared with the FL fraction. It did however not share any
TF1

TF2

FL B-LBL FL B-LBL -

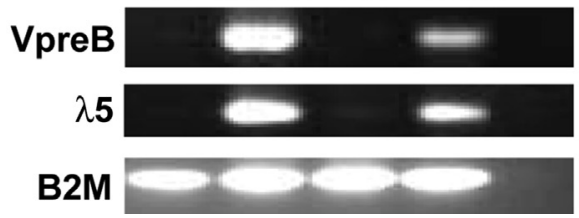

TF3

\begin{tabular}{llll}
\hline B-LBL & FL & FL & B-LBL
\end{tabular}

(S) $\mathrm{CD} 10^{\text {hi }} \mathrm{CD} 10^{\text {low }}(\mathrm{L})$

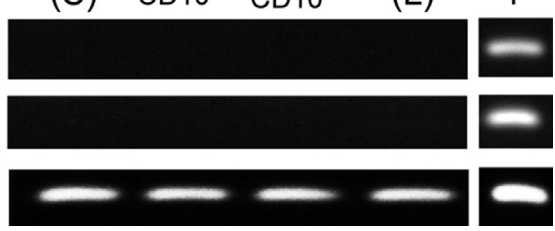

Figure 3 VpreB and $\lambda 5$ are expressed in the BLBL but not in the FL. RT-PCR analysis of VpreB and Lambda5 expression before and after progression. TF3 was sorted in four fractions (Supplemental Figure S1 and text). The - indicates a negative water control and the pre-B-cell line Nalm-6 was used as a positive control (+). B2M, $\beta-2-$ microglobulin; B-LBL, B-lymphoblastic lymphoma; $\mathrm{FL}$, follicular lymphoma; L, large; S, small. 
Table 4 Chromosomal Translocations Detected by FISH Analysis

\begin{tabular}{llll}
\hline Patient & BCL2 & MYC & BCL6 \\
\hline TF1a & + & - & + \\
TF1b & + & + & - \\
TF2a & NI & - & - \\
TF2c & + & + & + \\
TF3a & + & - & - \\
TF3b & + & + & - \\
TF4a & + & - & - \\
TF4b & + & - & ND \\
TF4c & + & + & - \\
\hline
\end{tabular}

$\mathrm{BCL}$, B-cell lymphoma; FISH, fluorescence in situ hybridization; ND, not determined; NI, not interpretable.

of the aberrations found in the transformed B-LBL, suggesting that this fraction is a subclone of the FL rather than a tumor population at an intermediate stage between FL and B-LBL.

WES revealed heterozygous missense mutations in CCND3, DYSF, ISOC2, and ZFHX4 present in the B-LBL, which were absent in the FL. Two missense mutations (in SMARCA2 and SNAPC3) heterozygously present in the FL were hemizygous in the B-LBL due to LOH of chromosome 9p. In addition, one nonsense mutation in TNFRSF14 and additional mutations in the $5^{\prime}$ untranslated region of $B C L 2$ and $M Y C$ were found in the B-LBL (Table 6 and Supplemental Figure S2). The mutations in CCND3, ISOC2, $M Y C$, and ZFHX4 were found in 7\%, 9\%, 3\%, and 6\% of the sequence reads, respectively, and thus were subclonal variants in the FL. Next to this analysis, we checked a set of genes previously described to be mutated in FL and B-ALL (see Materials and Methods). This unveiled missense mutations in $F M N 2, N E B$, and $S Y N E 1$, as well as a nonsense mutation in $K M T 2 D$, were shared by the FL and B-LBL. In addition, 1 synonymous, $23^{\prime}$ untranslated region, and 14 intronic mutations were identified (Supplemental Table S2). Eleven mutations in 10 genes were validated by Sanger sequencing in TF3b (Supplemental Figure S2). These mutations were also examined in TF1a, TF2a, and TF2c but were however not detected (data not shown). Moreover, no mutations in the commonly mutated gene EZH2 were detected in TF1a and TF3b. The loss of $C D K N 2 A / B$ as detected by CGH was confirmed by comparing the numbers of sequence reads (data not shown).

\section{Discussion}

Transformation of FL into a B-LBL occurs rarely and has been documented for a limited number of cases. ${ }^{7-15}$ Here, we describe four B-LBLs that evolved out of FLs and show that, despite retained expression of mutated IGHV genes, the B-LBLs had acquired several key features of precursor $\mathrm{B}$ cells. The follicular architecture as well as CD20 expression were lost; the expression of TdT, VpreB, and Lambda5 was induced; and evidence was obtained for reinitiated IGLV gene rearrangement because the expressed IGLV genes in the B-LBL of TF1b and TF2b were different from those of the FL of TF1a and TF2a, respectively, whereas the IGHV genes were unaltered.

A $t(14 ; 18)(\mathrm{q} 32 ; \mathrm{q} 21)$ is a rare event in primary B-LBL/BALL. Stamatoullas et $\mathrm{al}^{29}$ reported that of 142 adult B-ALLs, only 5 had a translocation involving the $B C L 2$ gene. The Mitelman database (http://cgap.nci.nih.gov/Chromosomes/ Mitelman, last accessed June 30, 2016) contains 12 de novo B-LBLs that harbor both a $B C L 2$ and a $M Y C$ translocation. In the studies assembled in the Mitelman database no IGHV sequence analyses were performed; thus, it is not excluded that the $\mathrm{t}(14 ; 18)^{+}$B-LBLs include cases that originate from FL.

Here, in all four lymphomas a $M Y C$ translocation was gained on histologic transformation. Secondary MYC translocations have been reported by others in 18 of 19 FLs transforming into B-LBLs, ${ }^{7-15}$ suggesting that MYC overexpression is mandatory for transformation into a B-LBL. However, this event by itself is unlikely to impose an immature B-cell program, given that $10 \%$ of FLs transforming into a DLBCL also carry $M Y C$ rearrangements. ${ }^{30}$ Remarkably, in the FL of TF3, MYC was amplified before translocation as determined by CGH. It has been reported in mice that MYC translocation is promoted by activationinduced cytidine deaminase (AID) activity. ${ }^{31}$ In this respect, the observations that the FLs of TF2 and TF3 display intraclonal IGHV sequence variation and that all four FLs express $\mathrm{IgG}$, whereas most FLs express $\operatorname{IgM},{ }^{2}$ are noteworthy and likely to be AID mediated. However, by RT-PCR we detected no AID expression in TF1, TF2, or TF3 (data not shown). Interestingly, $\mathrm{IgG}$ expression was also noticed in two separately reported FLs that transformed into B-LBLs. ${ }^{13,14}$

In TF2, progression to B-LBL was accompanied by a break at 3q27. Similarly, BCL6 translocations have also been documented in other de novo $\mathrm{t}(14 ; 18)^{+}$B-LBLs. $^{29}$ $B C L 6$ region translocations are known to occur in $6 \%$ to $10 \%$ of (grade 3) $\mathrm{FLs}^{32}$ approximately $30 \%$ of DLBCLs, ${ }^{32}$ and approximately $10 \%$ of FLs transforming into DLBCL. ${ }^{33}$ TF2b is a so-called triple-hit lymphoma carrying rearrangements of the $B C L 2, B C L 6$, and $M Y C$ genes. This combination of genomic rearrangements has been reported before in sporadic cases of FL undergoing transformation to DLBCLs as well as in de novo DLBCLs. ${ }^{6,34,35}$ Both the $\mathrm{t}(14 ; 18)(\mathrm{q} 32 ; \mathrm{q} 21)$ and the $\mathrm{t}(8,14)(\mathrm{q} 22 ; \mathrm{q} 32)$ disrupt the $I G$ coding region. ${ }^{36,37}$ However, the finding that in TF2b IGHV mRNA is still expressed is not necessarily contradictory because $B C L 6$ locus rearrangements may engage the $I G L$ chain or non$I G$ loci, whereas $M Y C$ may be juxtaposed to downstream $I G$ switch regions, thus leaving the $I G$ coding region intact. $^{38}$ Alternatively, BCL2 and $M Y C$ rearrangements may occur at the same $I G H$ allele. ${ }^{39}$ The phenomenon that in TF1 the break at the 3q27 locus was no longer detected after progression into the B-LBL of TF1b has been reported in FLs transformed to DLBCL. ${ }^{40}$ 
A

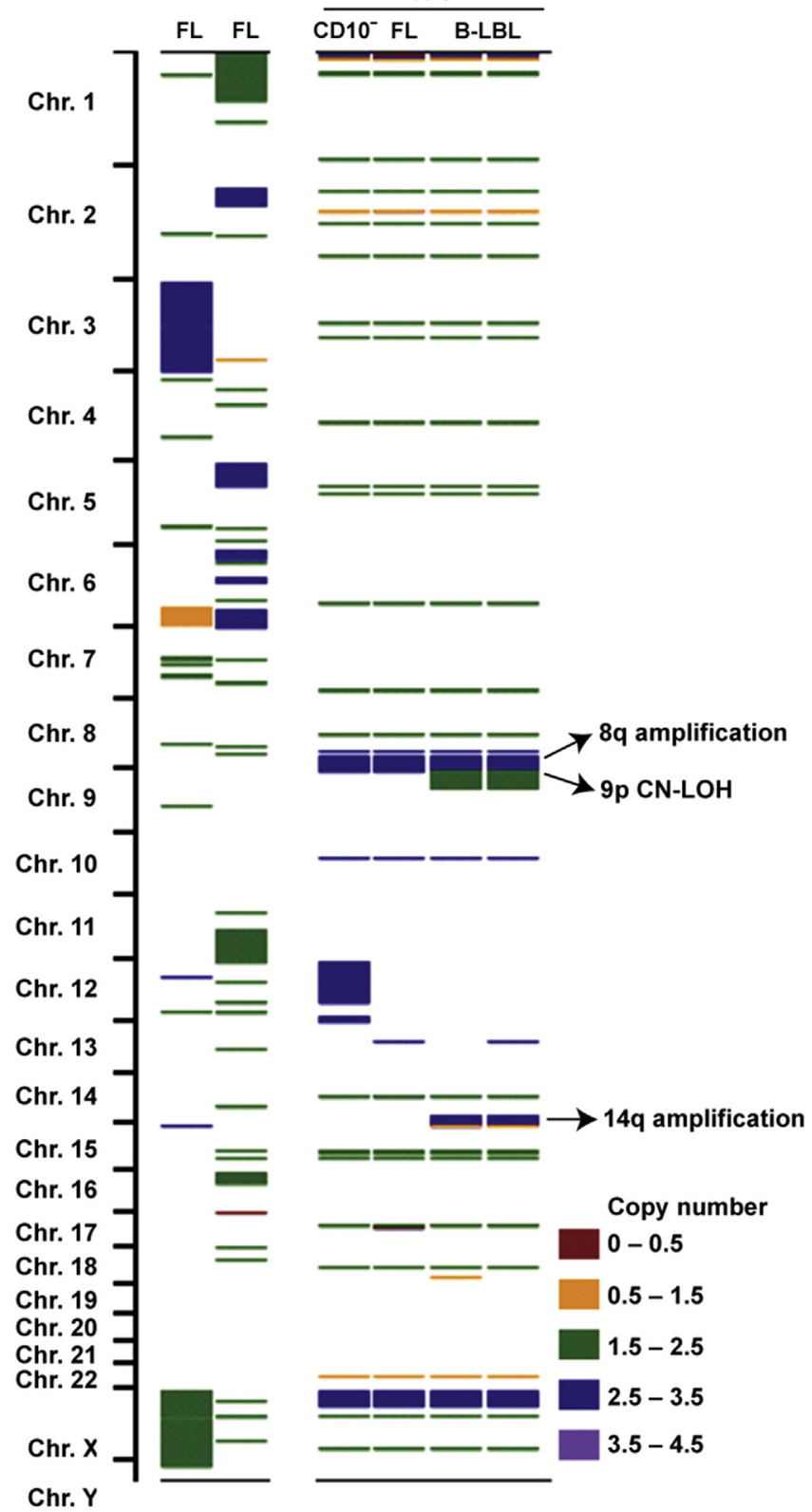

Figure 4 Genomic aberrations of TF3b FL and B-LBL as determined by comparative genomic hybridization. A: Overview of genomic aberrations of the four sorted cell populations of TF3b and two control FLs, as determined by comparative genomic hybridization. Red indicates homozygous deletion. Orange indicates heterozygous deletion. Green indicates $\mathrm{CN}-\mathrm{LOH}$. Blue indicates twofold amplification. Purple indicates greater than threefold amplification. B: Allele frequency of chromosome $9 p$ in the $\mathrm{B}-\mathrm{LBL}$ of TF3b. The green area indicates $\mathrm{CN}-\mathrm{LOH}$. Red indicates deletion. B-LBL, B-lymphoblastic lymphoma; Chr, chromosome; $\mathrm{CN}-\mathrm{LOH}$, copy-neutral loss of heterozygosity; FL, follicular lymphoma; Freq, frequency.

B

Chr. 9p in B-LBL

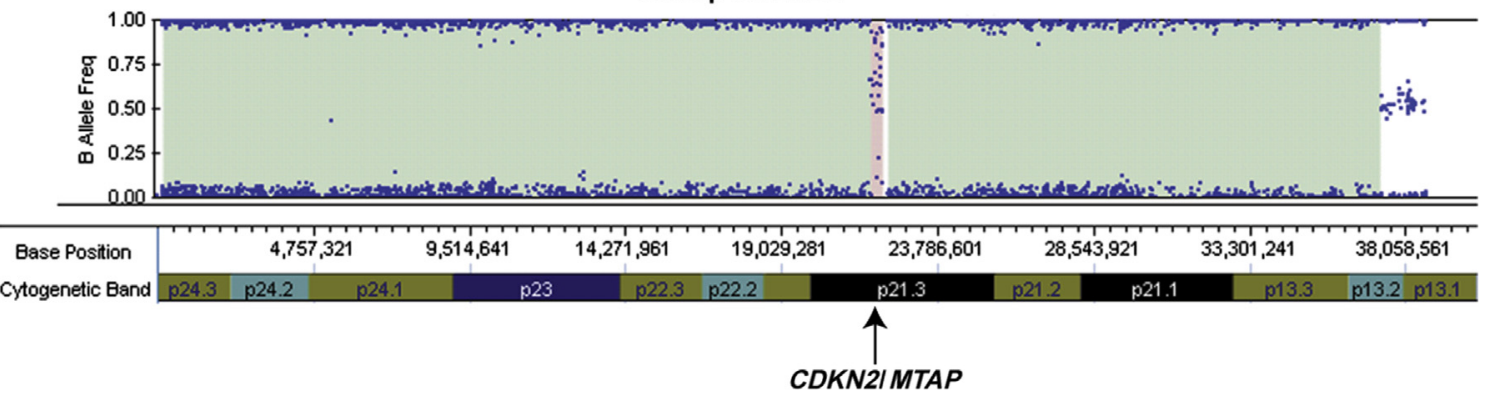

High-resolution CGH array on sorted FL and B-LBL cells from $\mathrm{TF} 3 \mathrm{~b}$ revealed that the $\mathrm{B}-\mathrm{LBL}$ had gained only a limited number of genetic aberrations, that is, $\mathrm{CN}-\mathrm{LOH}$ of 9p; deletion of 17q12; amplification of the oncogenes TCL1,
$B C L 11 B$, and $A K T$, all on chromosome 14; and amplification of $14 \mathrm{q} 32$ which includes the gene encoding the transcription factor Yin Yang 1 (YY1). YY1 is expressed in early B cells and GC B cells, where it regulates 
Table 5 Numerical Genomic Aberrations in TF3

\begin{tabular}{|c|c|c|c|}
\hline Region & $\mathrm{FL}$ & $B-L B L$ & Remarks \\
\hline $1 p 36$ & Del. & Del. & $\begin{array}{l}\text { Associated with } \\
\text { transformation of FL }\end{array}$ \\
\hline $2 \mathrm{p} 16$ & $\mathrm{CN}-\mathrm{LOH}$ & $\mathrm{CN}-\mathrm{LOH}$ & $\begin{array}{l}\text { Ampl. associated with } \\
\text { transformation of } \mathrm{FL}\end{array}$ \\
\hline $5 p 12$ & $\mathrm{CN}-\mathrm{LOH}$ & $\mathrm{CN}-\mathrm{LOH}$ & $\begin{array}{l}\text { Ampl. associated with } \\
\text { transformation of } \mathrm{FL}\end{array}$ \\
\hline $6 q 21$ & $\mathrm{CN}-\mathrm{LOH}$ & $\mathrm{CN}-\mathrm{LOH}$ & Del. in $17 \%$ of $\mathrm{FL}^{28}$ \\
\hline $6 q 22$ & $\mathrm{CN}-\mathrm{LOH}$ & $\mathrm{CN}-\mathrm{LOH}$ & $\begin{array}{l}\text { Ampl. associated with } \\
\text { transformation of FL }\end{array}$ \\
\hline $7 q 33$ & $\mathrm{CN}-\mathrm{LOH}$ & $\mathrm{CN}-\mathrm{LOH}$ & $\mathrm{LOH}$ in $11 \%$ of $\mathrm{FL}^{28}$ \\
\hline $8 q$ & Ampl. & Ampl. & Includes ampl. of $M Y C$ \\
\hline $9 p$ & WT & $\mathrm{CN}-\mathrm{LOH}$ & Includes del. of CDKN2 \\
\hline $14 q 32$ & WT & Ampl. & $\begin{array}{l}\text { Includes ampl. of TCL1 } \\
\text { and } B C L 11\end{array}$ \\
\hline $17 q 12$ & WT & Del. & Includes del. of $N F-1$ \\
\hline $22 q 11$ & Del. & Del. & Del. in $10 \%$ of $\mathrm{FL}^{28}$ \\
\hline
\end{tabular}

Ampl., amplification; B-LBL, precursor B-cell lymphoblastic lymphoma; $\mathrm{CN}-\mathrm{LOH}$, copy neutral loss of heterozygosity; Del., deletion; $\mathrm{FL}$, follicular lymphoma; WT, wild-type.

$I G H V$-rearrangement and class switch recombination, respectively. ${ }^{41}$ YY1 has also been shown to activate the $M Y C$ promotor. $^{42}$ The deleted 9p region contains CDKN2A/ $B$ and $M T A P$ and was previously described to be associated with transformation of FL into DLBCL. ${ }^{5}$ Loss of CDKN2A/ $B$ also occurs in approximately $40 \%$ of adult B-ALLs and is associated with poor survival. ${ }^{43}$ Deletion of the cell cycle regulators $C D K N 2 A / B$ may be required for transformation because it renders the cells resistant to $M Y C$-induced apoptosis. ${ }^{5}$ It is, however, unlikely that $C D K N 2 A / B$ loss is instrumental in the induction of a precursor B-cell phenotype.

$P A X 5$, a master regulator of $\mathrm{B}$-cell lineage commitment and differentiation ${ }^{44}$ is among the genes on $9 p$ that show LOH after transformation (listed in Supplemental Table S2). Interestingly, mutations in PAX5 were found in approximately $30 \%$ of de novo B-LBLs, suggesting that loss of expression of this transcription factor results in a developmental blockade and drives B-LBL development. ${ }^{44}$
Moreover, it was shown that $P A X 5^{-1-}$ mice have a differentiation arrest at the pro-B-cell stage, ${ }^{44}$ whereas targeted deletion of PAX5 in mature B cells resulted in loss of the Bcell phenotype and lymphoblast formation. ${ }^{45}$ However, we did not detect mutations in the coding region of PAX5 in TF1, TF2, and TF3 (data not shown), and PAX5 protein expression was measurable by IHC in all four B-LBLs (Table 2). Still, decreased PAX5 transcription and protein expression due to the $9 \mathrm{p}$ deletion cannot be excluded. Neither did we detect mutations in IKZFI in TF3 (data not shown), another master regulator of B-cell commitment and differentiation, which is frequently deleted in de novo B-LBL. ${ }^{44}$

WES revealed missense mutations in $F M N 2, N E B$, and $S Y N E 1$ as well as a nonsense mutation in KMT2D, shared by the FL (TF3a) and B-LBL (TF3b) (Supplemental Table S1). These genes were previously described to be mutated in FL. ${ }^{5,22-26} K M T 2 D$ has a role in epigenetic programming and is considered as a driver gene of FL. ${ }^{22}$ Compared with the preceding FL (TF3a), seven missense mutations and one nonsense mutation were gained in the B-LBL stage. One of the missense mutations in CCND3 (T283A) is located in exon 5 , a region recurrently mutated in DLBCL and BL. In $38 \%$ of sporadic BL cases a mutation in CCND3 is present. ${ }^{46}$ The T283A mutation was shown to increase protein stability of CCND3 conferring a proliferative advantage. ${ }^{46}$ In the FL stage, a deletion of chromosome $1 \mathrm{p} 36$ was detected, including deletion of TNFRSF14. In FL, $-1 \mathrm{p} 36$ is found in frequencies between $20 \%$ and $40 \%$ and has been correlated with dismal prognosis. ${ }^{28,47}$ Interestingly, in addition to $-1 \mathrm{p} 36$, in the TF3b B-LBL a nonsense mutation in TNFRSF14 was found, suggestive for a tumor suppressor role in the progression of FL. However, there are conflicting reports as to whether the combination of $-1 \mathrm{p} 36$ with TNFRSF14 mutation is associated with good or bad overall survival. ${ }^{48,49}$ Interestingly, the mutation in SMARCA2 (BRM), which is part of the switch/sucrose non-fermentable ATP-dependent chromatin remodeling complex, was hemizygously found in the B-LBL stage due to LOH on chromosome $9 \mathrm{p} .{ }^{50}$ Mutations in SMARCA2 and

Table 6 Exome Mutations Gained in the B-LBL of TF3b

\begin{tabular}{|c|c|c|c|c|c|c|c|}
\hline Gene & Chromosome & Position & Mutation type & RefSeq & Mutation & $\mathrm{FL}$ & B-LBL \\
\hline$B C L 2$ & 18 & 60986079 & $5^{\prime}$ UTR & NM_00633 & $5^{\prime}$ UTR-180 C/T & WT & Het \\
\hline CCND3 & 6 & 41903710 & Missense & NM_001760 & K268R (A803G) & WT & Het \\
\hline DYSF & 2 & 71908237 & Missense & NM_01130987 & P20570 (C6170A) & WT & Het \\
\hline ISOC2 & 19 & 55967760 & Missense & NM_01136201 & G94A (A32T) & WT & Het \\
\hline$M Y C$ & 8 & 128748820 & $5^{\prime}$ UTR & NM_002467 & $5^{\prime}$ UTR+19 T/C & WT & Het \\
\hline TNFRSF14 & 1 & 2488138 & Nonsense & NM_003820 & W12* $(\mathrm{G} 35 \mathrm{~A})$ & WT & Hom \\
\hline ZFHX4 & 8 & 77763412 & Missense & NM_024721 & H1419Y (C4255T) & WT & Het \\
\hline
\end{tabular}

B-LBL, precursor B-cell lymphoblastic lymphoma; FL, follicular lymphoma; Hem, hemizygous; Het, heterozygous; Hom, homozygous; UTR, untranslated region; WT, wild-type. 
SMARCA4 were described in marginal zone B-cell lymphoma, ${ }^{50} \mathrm{BL}$, and DLBCL. ${ }^{46}$ SMARCA2 is a known interaction partner of $\mathrm{C} / \mathrm{EBP} \alpha$, which forms heterodimers with $\mathrm{C} / \mathrm{EPB} \beta .^{51}$ It has been shown that $\mathrm{C} / \mathrm{EPB} \alpha$ and $\mathrm{C} / \mathrm{EBP} \beta$ are involved in $\mathrm{B}$-cell reprogramming to macrophage-like cells or stem cell-like cells. However, it is unclear whether SMARCA2 interacts with the heterodimer of $\mathrm{C} / \mathrm{EPB} \alpha$ and $\mathrm{C} / \mathrm{EPB} \beta$ and whether this interaction is necessary for a role in B-cell reprogramming. ${ }^{52}$ In addition, switch/sucrose non-fermentable complex components, including SMARCA2, are necessary for the accessibility of the $C D 79 A$ promotor for the transcription factors PAX5 and EBF1. ${ }^{53}$ Via these mechanisms the identified mutation in SMARCA2 may contribute to the lymphoma de-differentiation. Some of the mutations that were specifically and uniformly detected in the B-LBL (in CCND3, ISOC2, MYC, and ZFHX4) were detectable in 3\% to $9 \%$ of the sequence reads in the preceding FL time point. This observation indicates that minor precursor clones containing these mutations were present in the FL. One subclone of the FL with all these mutations eventually grew out as the B-LBL.

In a recently published study by Geyer et $\mathrm{al}^{12}$ seven FLs, which transformed into B-LBLs, were analyzed. Similar to our study, all transformation cases were characterized by loss of follicular architecture, gain of TdT expression, and the presence of a MYC gene rearrangement. The lymphoblastic lymphoma of one case was analyzed by WES also identifying mutations in TNFRSF14 and CCND3. Unfortunately, it is unknown whether these mutations had been present in the FL, because the preceding FL was not analyzed.

Some of the genomic mutations acquired in the B-LBL are also implicated in the transformation from $\mathrm{FL}$ to DLBCL, such as deletion of $C D K N 2 A / B$ and $M Y C$ translocation. $M Y C$ translocation is also essential in BL development, and the acquired CCND3 mutation (T283A) is frequently mutated in this aggressive lymphoma. Although we also determined several acquired mutations, which were not described in either DLBCL or BL and intriguingly all FLs transforming to B-LBL expressed $\mathrm{IgG}$, we cannot explain this peculiar transformation.

It was previously hypothesized that clonally related FLs and B-LBLs do not develop sequentially but might evolve in parallel from precursor cells harboring the $\mathrm{t}(14 ; 18){ }^{8,36} \mathrm{~A}$ $\mathrm{t}(14 ; 18)^{+} \mathrm{sIG}^{-}$and $\mathrm{TdT}^{+} \mathrm{B}$ cell might thus evolve into a $\mathrm{TdT}^{-} \mathrm{CD} 20^{+} \mathrm{FL}$ or expand as a precursor $\mathrm{B}$ cell by acquisition of an additional MYC translocation. However, more recent work has shown that after the acquisition of the $t(14 ; 18)$ in bone marrow precursor B cells, these $t(14 ; 18)^{+}$ $B$ cells further mature to memory B cells and acquire somatic hypermutations in successive rounds of re-entry in germinal centers. ${ }^{54}$ Thus, the B-LBL might originate from mature postgerminal center $\mathrm{B}$ cells functioning as $\mathrm{FL}$ precursor cells that undergo a further round of re-entry in a germinal center, thereby acquiring an AID-induced MYC breakpoint. For still unknown reasons they also show partial regression to a phenotype of precursor B cells. Our study, however, demonstrates that the B-LBLs evolve from FL subclones that already accumulated most (for TF2 all) of the somatic IGHV mutations and for TF3 also most of the genomic aberrations. Whatever the exact mechanism may be, these data clearly show that the FL and B-LBL pairs did not arise in parallel from $t(14 ; 18)^{+}$Ig unmutated precursor cells.

\section{Acknowledgments}

We thank Berend Hooibrink for FACS-sorting.

L.M.S., R.H., L.A.S., R.J.B., and C.J.M.v.N. designed the research; L.M.S., R.H., L.A.S., T.A.M.W., M.E.C.M.O., E.J.M.S.-T., A.B.M., and R.J.B. performed the research; P.M.K. and B.J.B. provided patient material; L.M.S., R.H., L.A.S., A.J., A.H.C.v.K., J.E.J.G., R.J.B., and C.J.M.v.N. analyzed the data; L.M.S., R.H., L.A.S., R.J.B., and C.J.M.v.N. wrote the manuscript; and all authors edited the manuscript.

\section{Supplemental Data}

Supplemental material for this article can be found at http://dx.doi.org/10.1016/j.ajpath.2016.07.027.

\section{References}

1. Jaffe E, Harris RS, Stein H, Vardiman JW: WHO Classification of Tumours of Haematopoietic and Lymphoid Tissues. Washington: IARC press, 2008

2. Bende RJ, Smit LA, van Noesel CJ: Molecular pathways in follicular lymphoma. Leukemia 2007, 21:18-29

3. Aarts WM, Bende RJ, Steenbergen EJ, Kluin PM, Ooms EC, Pals ST, van Noesel CJ: Variable heavy chain gene analysis of follicular lymphomas: correlation between heavy chain isotype expression and somatic mutation load. Blood 2000, 95:2922-2929

4. Roulland S, Faroudi M, Mamessier E, Sungalee S, Salles G, Nadel B Early steps of follicular lymphoma pathogenesis. Adv Immunol 2011, 111:1-46

5. Pasqualucci L, Khiabanian H, Fangazio M, Vasishtha M, Messina M, Holmes AB, Ouillette P, Trifonov V, Rossi D, Tabbo F, Ponzoni M, Chadburn A, Murty VV, Bhagat G, Gaidano G, Inghirami G, Malek SN, Rabadan R, Dalla-Favera R: Genetics of follicular lymphoma transformation. Cell Rep 2014, 6:130-140

6. Aukema SM, Siebert R, Schuuring E, van Imhoff GW, KluinNelemans HC, Boerma EJ, Kluin PM: Double-hit B-cell lymphomas. Blood 2011, 117:2319-2331

7. Ning Y, Foss A, Kimball AS, Neill N, Matz T, Schultz R: Characterization of a case of follicular lymphoma transformed into B-lymphoblastic leukemia. Mol Cytogenet 2013, 6:34

8. Young KH, Xie Q, Zhou G, Eickhoff JC, Sanger WG, Aoun P, Chan WC: Transformation of follicular lymphoma to precursor B-cell lymphoblastic lymphoma with c-myc gene rearrangement as a critical event. Am J Clin Pathol 2008, 129:157-166

9. Kaplan A, Samad A, Dolan MM, Cioc AM, Holman CJ, Schmechel SC, Pambuccian SE: Follicular lymphoma transformed to "double-hit" B lymphoblastic lymphoma presenting in the peritoneal fluid. Diagn Cytopathol 2013, 41:986-990 
10. Sun X, Gordon LI, Peterson LC: Transformation of follicular lymphoma to acute lymphoblastic leukemia. Arch Pathol Lab Med 2002, 126:997-998

11. Mannouji K, Tasaka T, Akiyama T, Irei I, Sano F, Matsuhashi Y, Wada H, Tohyama K, Sugihara T, Sadahira Y: Transformation from follicular lymphoma to high-grade B-cell lymphoma/leukemia with additional $\mathrm{t}(2 ; 8)(\mathrm{p} 12 ; \mathrm{q} 24)$, with inverse expressions of $\mathrm{c}-\mathrm{MYC}$ and BCL-2, and light-chain switch. Pathol Int 2009, 59:261-264

12. Geyer JT, Subramaniyam S, Jiang Y, Elemento O, Ferry JA, de Leval L, Nakashima MO, Liu YC, Martin P, Mathew S, Orazi A, Tam W: Lymphoblastic transformation of follicular lymphoma: a clinicopathologic and molecular analysis of 7 patients. Hum Pathol 2015, 46:260-271

13. Fiedler W, Weh HJ, Zeller W, Fonatsch C, Hillion J, Larsen C, Wormann B, Hossfeld DK: Translocation $(14 ; 18)$ and $(8 ; 22)$ in three patients with acute leukemia/lymphoma following centrocytic/centroblastic non-Hodgkin's lymphoma. Ann Hematol 1991, 63: $282-287$

14. Gauwerky CE, Hoxie J, Nowell PC, Croce CM: Pre-B-cell leukemia with a $t(8 ; 14)$ and a $t(14 ; 18)$ translocation is preceded by follicular lymphoma. Oncogene 1988, 2:431-435

15. Kobrin C, Cha SC, Qin H, Raffeld M, Fend F, QuintanillaMartinez L, Grove S, Jaffe ES, Kwak LW: Molecular analysis of light-chain switch and acute lymphoblastic leukemia transformation in two follicular lymphomas: implications for lymphomagenesis. Leuk Lymphoma 2006, 47:1523-1534

16. Aarts WM, Willemze R, Bende RJ, Meijer CJ, Pals ST, van Noesel CJ: VH gene analysis of primary cutaneous B-cell lymphomas: evidence for ongoing somatic hypermutation and isotype switching. Blood 1998, 92:3857-3864

17. van Dongen JJ, Langerak AW, Bruggemann M, Evans PA, Hummel M, Lavender FL, Delabesse E, Davi F, Schuuring E, GarciaSanz R, van Krieken JH, Droese J, Gonzalez D, Bastard C, White HE, Spaargaren M, Gonzalez M, Parreira A, Smith JL, Morgan GJ, Kneba M, Macintyre EA: Design and standardization of PCR primers and protocols for detection of clonal immunoglobulin and T-cell receptor gene recombinations in suspect lymphoproliferations: report of the BIOMED-2 Concerted Action BMH4-CT98-3936. Leukemia 2003, 17:2257-2317

18. Brochet X, Lefranc MP, Giudicelli V: IMGT/V-QUEST: the highly customized and integrated system for IG and TR standardized V-J and V-D-J sequence analysis. Nucleic Acids Res 2008, 36: W503-W508

19. Fenton JA, Vaandrager JW, Aarts WM, Bende RJ, Heering K, van Dijk M, Morgan G, van Noesel CJ, Schuuring E, Kluin PM: Follicular lymphoma with a novel $t(14 ; 18)$ breakpoint involving the immunoglobulin heavy chain switch mu region indicates an origin from germinal center B cells. Blood 2002, 99:716-718

20. Attiyeh EF, Diskin SJ, Attiyeh MA, Mossé YP, Hou C, Jackson EM, Kim C, Glessner J, Hakonarson H, Biegel JA, Maris JM: Genomic copy number determination in cancer cells from single nucleotide polymorphism microarrays based on quantitative genotyping corrected for aneuploidy. Genome Res 2009, 19:276-283

21. Houten SM, Denis S, Te Brinke H, Jongejan A, van Kampen AH, Bradley EJ, Baas F, Hennekam RC, Millington DS, Young SP, Frazier DM, Gucsavas-Calikoglu M, Wanders RJ: Mitochondrial NADP $(H)$ deficiency due to a mutation in NADK2 causes dienoylCoA reductase deficiency with hyperlysinemia. Hum Mol Genet 2014, 23:5009-5016

22. Morin RD, Mendez-Lago M, Mungall AJ, Goya R, Mungall KL, Corbett RD, et al: Frequent mutation of histone-modifying genes in non-Hodgkin lymphoma. Nature 2011, 476:298-303

23. Green MR, Gentles AJ, Nair RV, Irish JM, Kihira S, Liu CL, Kela I, Hopmans ES, Myklebust JH, Ji H, Plevritis SK, Levy R, Alizadeh AA: Hierarchy in somatic mutations arising during genomic evolution and progression of follicular lymphoma. Blood 2013, 121: $1604-1611$
24. Zhang J, Mullighan CG, Harvey RC, Wu G, Chen X, Edmonson M, Buetow KH, Carroll WL, Chen IM, Devidas M, Gerhard DS, Loh ML, Reaman GH, Relling MV, Camitta BM, Bowman WP, Smith MA, Willman CL, Downing JR, Hunger SP: Key pathways are frequently mutated in high-risk childhood acute lymphoblastic leukemia: a report from the Children's Oncology Group. Blood 2011, 118:3080-3087

25. Okosun J, Bodor C, Wang J, Araf S, Yang CY, Pan C, Boller S, Cittaro D, Bozek M, Iqbal S, Matthews J, Wrench D, Marzec J, Tawana K, Popov N, O'Riain C, O'Shea D, Carlotti E, Davies A, Lawrie CH, Matolcsy A, Calaminici M, Norton A, Byers RJ, Mein C, Stupka E, Lister TA, Lenz G, Montoto S, Gribben JG, Fan Y, Grosschedl R, Chelala C, Fitzgibbon J: Integrated genomic analysis identifies recurrent mutations and evolution patterns driving the initiation and progression of follicular lymphoma. Nat Genet 2014, 46:176-181

26. Green MR, Kihira S, Liu CL, Nair RV, Salari R, Gentles AJ, Irish J, Stehr H, Vicente-Duenas C, Romero-Camarero I, Sanchez-Garcia I, Plevritis SK, Arber DA, Batzoglou S, Levy R, Alizadeh AA: Mutations in early follicular lymphoma progenitors are associated with suppressed antigen presentation. Proc Natl Acad Sci U S A 2015, 112:E1116-E1125

27. Lemmers B, Arnoulet C, Fossat C, Chambost H, Sainty D, Gabert J, Schiff C: Fine characterization of childhood and adult acute lymphoblastic leukemia (ALL) by a proB and preB surrogate light chain-specific $\mathrm{mAb}$ and a proposal for a new B cell ALL classification. Leukemia 2000, 14:2103-2111

28. Cheung KJ, Shah SP, Steidl C, Johnson N, Relander T, Telenius A, Lai B, Murphy KP, Lam W, Al-Tourah AJ, Connors JM, Ng RT, Gascoyne RD, Horsman DE: Genome-wide profiling of follicular lymphoma by array comparative genomic hybridization reveals prognostically significant DNA copy number imbalances. Blood 2009, 113:137-148

29. Stamatoullas A, Buchonnet G, Lepretre S, Lenain P, Lenormand B, Duval C, Callat MP, Gaulard P, Bastard C, Tilly H: De novo acute B cell leukemia/lymphoma with $\mathrm{t}(14 ; 18)$. Leukemia 2000, 14: 1960-1966

30. Yano T, Jaffe ES, Longo DL, Raffeld M: MYC rearrangements in histologically progressed follicular lymphomas. Blood 1992, 80: 758-767

31. Robbiani DF, Bunting S, Feldhahn N, Bothmer A, Camps J, Deroubaix S, McBride KM, Klein IA, Stone G, Eisenreich TR, Ried T, Nussenzweig A, Nussenzweig MC: AID produces DNA double-strand breaks in non-Ig genes and mature B cell lymphomas with reciprocal chromosome translocations. Mol Cell 2009, 36:631-641

32. Lo Coco F, Ye BH, Lista F, Corradini P, Offit K, Knowles DM, Chaganti RS, Dalla-Favera R: Rearrangements of the BCL6 gene in diffuse large cell non-Hodgkin's lymphoma. Blood 1994, 83: $1757-1759$

33. Martinez-Climent JA, Alizadeh AA, Segraves R, Blesa D, RubioMoscardo F, Albertson DG, Garcia-Conde J, Dyer MJ, Levy R, Pinkel D, Lossos IS: Transformation of follicular lymphoma to diffuse large cell lymphoma is associated with a heterogeneous set of DNA copy number and gene expression alterations. Blood 2003, 101: 3109-3117

34. Ueda C, Nishikori M, Kitawaki T, Uchiyama T, Ohno H: Coexistent rearrangements of c-MYC, BCL2, and BCL6 genes in a diffuse large B-cell lymphoma. Int J Hematol 2004, 79:52-54

35. Martin-Subero JI, Odero MD, Hernandez R, Cigudosa JC, Agirre X, Saez B, Sanz-Garcia E, Ardanaz MT, Novo FJ, Gascoyne RD, Calasanz MJ, Siebert R: Amplification of IGH/MYC fusion in clinically aggressive IGH/BCL2-positive germinal center B-cell lymphomas. Genes Chromosomes Cancer 2005, 43:414-423

36. de Jong D, Voetdijk BM, van Ommen GJ, Kluin-Nelemans JC, Beverstock GC, Kluin PM: Translocation $\mathrm{t}(14 ; 18)$ in B cell lymphomas as a cause for defective immunoglobulin production. J Exp Med 1989, 169:613-624

37. Hecht JL, Aster JC: Molecular biology of Burkitt's lymphoma. J Clin Oncol 2000, 18:3707-3721 
38. Guikema JE, Fenton JA, de Boer C, Kleiverda K, Brink AA, Raap AK, Estrov Z, Schuuring E, Kluin PM: Complex biallelic IGH rearrangements in IgM-expressing Z-138 cell line: involvement of downstream immunoglobulin class switch recombination. Genes Chromosomes Cancer 2005, 42:164-169

39. Knezevich S, Ludkovski O, Salski C, Lestou V, Chhanabhai M, Lam W, Klasa R, Connors JM, Dyer MJ, Gascoyne RD, Horsman DE: Concurrent translocation of BCL2 and MYC with a single immunoglobulin locus in high-grade B-cell lymphomas. Leukemia 2005, 19:659-663

40. Lossos IS, Levy R: Higher grade transformation of follicular lymphoma: phenotypic tumor progression associated with diverse genetic lesions. Semin Cancer Biol 2003, 13:191-202

41. Zaprazna K, Atchison ML: YY1 controls immunoglobulin class switch recombination and nuclear activation-induced deaminase levels. Mol Cell Biol 2012, 32:1542-1554

42. Riggs KJ, Saleque S, Wong KK, Merrell KT, Lee JS, Shi Y, Calame K: Yin-yang 1 activates the c-myc promoter. Mol Cell Biol 1993, 13:7487-7495

43. Kim M, Yim SH, Cho NS, Kang SH, Ko DH, Oh B, Kim TY, Min HJ, She CJ, Kang HJ, Shin HY, Ahn HS, Yoon SS, Kim BK, Shin HR, Han KS, Cho HI, Lee DS: Homozygous deletion of CDKN2A (p16, p14) and CDKN2B (p15) genes is a poor prognostic factor in adult but not in childhood B-lineage acute lymphoblastic leukemia: a comparative deletion and hypermethylation study. Cancer Genet Cytogenet 2009, 195:59-65

44. Mullighan CG, Goorha S, Radtke I, Miller CB, Coustan-Smith E, Dalton JD, Girtman K, Mathew S, Ma J, Pounds SB, Su X, Pui CH, Relling MV, Evans WE, Shurtleff SA, Downing JR: Genome-wide analysis of genetic alterations in acute lymphoblastic leukaemia. Nature 2007, 446:758-764

45. Horcher M, Souabni A, Busslinger M: Pax5/BSAP maintains the identity of B cells in late B lymphopoiesis. Immunity 2001, 14:779-790

46. Schmitz R, Young RM, Ceribelli M, Jhavar S, Xiao W, Zhang M, et al: Burkitt lymphoma pathogenesis and therapeutic targets from structural and functional genomics. Nature 2012, 490:116-120
47. Hoglund M, Sehn L, Connors JM, Gascoyne RD, Siebert R, Sall T, Mitelman F, Horsman DE: Identification of cytogenetic subgroups and karyotypic pathways of clonal evolution in follicular lymphomas. Genes Chromosomes Cancer 2004, 39:195-204

48. Cheung KJ, Johnson NA, Affleck JG, Severson T, Steidl C, BenNeriah S, Schein J, Morin RD, Moore R, Shah SP, Qian H, Paul JE, Telenius A, Relander T, Lam W, Savage K, Connors JM, Brown C, Marra MA, Gascoyne RD, Horsman DE: Acquired TNFRSF14 mutations in follicular lymphoma are associated with worse prognosis. Cancer Res 2010, 70:9166-9174

49. Launay E, Pangault C, Bertrand P, Jardin F, Lamy T, Tilly H, Tarte K, Bastard C, Fest T: High rate of TNFRSF14 gene alterations related to $1 \mathrm{p} 36$ region in de novo follicular lymphoma and impact on prognosis. Leukemia 2012, 26:559-562

50. Martinez N, Almaraz C, Vaque JP, Varela I, Derdak S, Beltran S, Mollejo M, Campos-Martin Y, Agueda L, Rinaldi A, Kwee I, Gut M, Blanc J, Oscier D, Strefford JC, Martinez-Lopez J, Salar A, Sole F, Rodriguez-Peralto JL, Diez-Tascon C, Garcia JF, Fraga M, Sebastian E, Alves J, Menarguez J, Gonzalez-Carrero J, Casado LF, Bayes M, Bertoni F, Gut I, Piris MA: Whole-exome sequencing in splenic marginal zone lymphoma reveals mutations in genes involved in marginal zone differentiation. Leukemia 2014, 28:1334-1340

51. Muller C, Calkhoven CF, Sha X, Leutz A: The CCAAT enhancerbinding protein alpha (C/EBPalpha) requires a SWI/SNF complex for proliferation arrest. J Biol Chem 2004, 279:7353-7358

52. Di Stefano B, Sardina JL, van Oevelen C, Collombet S, Kallin EM, Vicent GP, Lu J, Thieffry D, Beato M, Graf T: C/EBPalpha poises B cells for rapid reprogramming into induced pluripotent stem cells. Nature 2014, 506:235-239

53. Gao H, Lukin K, Ramirez J, Fields S, Lopez D, Hagman J: Opposing effects of SWI/SNF and Mi-2/NuRD chromatin remodeling complexes on epigenetic reprogramming by EBF and Pax5. Proc Natl Acad Sci U S A 2009, 106:11258-11263

54. Mamessier E, Broussais-Guillaumot F, Chetaille B, Bouabdallah R, Xerri L, Jaffe ES, Nadel B: Nature and importance of follicular lymphoma precursors. Haematologica 2014, 99:802-810 